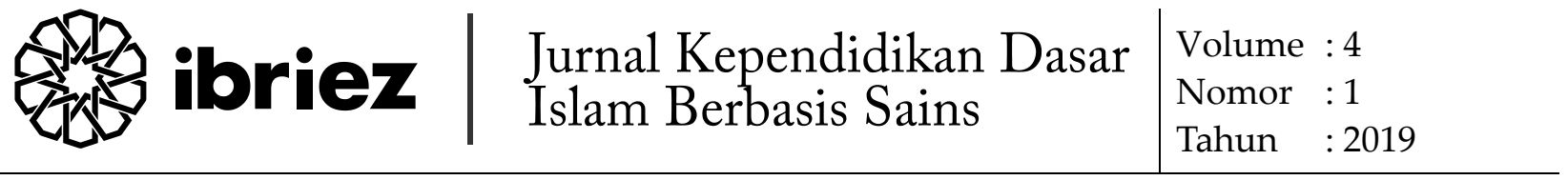

\title{
Diagnosa Kesulitan Mahasiswa PGMI IAIN Ponorogo Dalam Membelajarkan Bilangan Pecahan
}

\author{
Ulum Fatmahanik \\ Fakultas Tarbiyah dan Ilmu Keguruan \\ Institut Agama Islam Negeri Ponorogo \\ ulum.fatma@gmail.com
}

\begin{abstract}
Abstrak
Pecahan merupakan salah satu materi yang diajarkan dalam matematika yang mencakup konsep dasar dan materi prsayarat dalam mempelajari bilangan yang lain serta mengembangkan kemampuan penalaran aljabar mahasiswa. Tetapi kebanyakan mahasiswa calon guru SD/MI mengalami kesulitan dalam membelajarkan bilangan pecahan. Hal ini perlu dianalisis karena apabila calon seorang guru dalam mengajarkan banyak terjadi kesalahan maka dapat dipastikan bahwa siswa yang diajar juga akan mengalami hal yang sama. Sehingga sebagai mahasiswa calon guru SD/MI harus mempunyai bekal penguasaan materi yang memadai. Penelitian ini merupakan penelitian kualitatif yang menghasilkan data mengenai permasalahan mahasiwa PGMI IAIN dalam membelajarkan bilangan pecahan. Hasil penelitian menunjukkan bahwa permasalahan yang dialamai mahasiswa calon guru SD/MI dalam membelajarkan bilangan pecahan diantaranya yaitu: 1) kesulitan dalam membelajarkan makna pecahan, 2) kesulitan dalam membelajarkan pecahan senilai, 3) Kesulitan dalam membelajarkan penjumlahan bilangan bilangan pecahan jika mempunyai penyebut yang tidak sama, 4) Kesulitan dalam membelajarkan pengurangan bilangan pecahan dengan penyebut tidak sama, 5) Kesulitan dalam membelajarkan perkalian pecahan, 6) Mahasiswa mengalami kesulitan dalam membelajarkan makna dan hasil pembagian pecahan.
\end{abstract}

\section{Kata Kunci: Kesulitan, Membelajarkan, Bilangan Pecahan}

\section{Abstract}

Fraction is one of the material taught in mathematics which includes basic concepts and preparatory material in learning other numbers and developing student algebraic reasoning abilities. But most elementary school / MI teacher candidates have difficulty in learning fractions. This needs to be analyzed because if a prospective teacher teaches many mistakes, then it can be ascertained that students who are taught will also experience the same thing. So that as students of elementary / MI teacher candidates must have adequate mastery of material. This research is a qualitative research that produces data on the problems of PGMI IAIN students in learning fractions. The results showed that the problems experienced by $S D$ / MI teacher candidates in learning fractions include: 1) difficulties in teaching fractions of meaning, 2) difficulties in learning fractions worth, 3) Difficulties in teaching the sum 
of fractions if they have a denominator that is not same, 4) Difficulties in learning to reduce fractions with denominators are not the same, 5) Difficulties in learning fraction multiplication, 6) Students have difficulty in teaching the meaning and results of fraction distribution.

Keywords: Difficulties, Learning, Fractions

\section{A. PENDAHULUAN}

Matematika merupakan salah satu mata pelajaran yang dijadikan sebagai sarana untuk menumbuhkan dan mengembangkan kemampuan berpikir logis, sistematis, analitis, kritis, dan kreatif yang tentunya disesuaikan dengan perkembangan psikologi setiap siswa. menurut Cornelius terdapat 5 hal yang menyebabkan pentingnya matematika untuk diperlajari karena matematika merupakan sarana berfikir yang jelas dan logis, sarana untuk memecahkan masalah kehidupan seharihari, sarana mengenal pola-pola hubungan dan generalisasi pengalaman, sarana untuk mengembangkan kreativitas, dan sarana untuk meningkatkan kesadaran terhadap perkembangan budaya. ${ }^{1}$ Hal ini menyebabkan matematika wajib ditempuh disemua jenjang pendidikan mulia dari SD/MI sampai dengan jenjang perguruan tinggi.

Soedjaji menyatakan bahwa tujuan diajarkannya matematika dari setiap jenjang pendidikan karena matematika memiliki tujuan yang bersifat formal maupun material. Bersifat formal berarti bahwa dalam matematika lebih menekankan pada pembentukan penalaran dan pembentukan kepribadian. Sedangkan bersifat material karena dalam matematika

1 Ulum Fatmahanik, "Realistic Mathematic Education (RME) Dalam Meningkatkan Hasil Belajar Matematika," Ibriez: Jurnal Kependidikan Dasar Islam Berbasis Sains 1, no. 1 (2016): 19-34. juga menekankan pada aspek ketrampilan dalam menerapkan matematika. ${ }^{2}$
Adapun
tujuan
diajarkannya

matematika pada mahasiswa PGMI IAIN Ponorogo yang merupakan mahasiswa calon guru SD/MI pada mata kuliah pembelajaran matematika di SD/MI karena mata kuliah ini lebih menekankan pada membekali mahasiswa dan memberikan pemahaman kepada calon guru SD/MI tentang bagaimana kita membelajarkan, media apa yang akan kita gunakan serta strategi apa yang kan kita gunakan dalam membelajarkan matematika untuk siswa MI/SD. Melihat deskripsi capain dari mata kuliah ini berarti dalam hal ini belajar matematika mempunyai tujuan yang bersifat material.

Salah satu materi yang harus dikuasai oleh mahasiswa calon guru SD/MI adalah materi pecahan. Akan tetapi baik guru maupun siswa selalu mengalami kesulitan dalam menyelesaikan soal pecahan. Secara umum kemampuan siswa dalam menyelesaikan soal pecahan tergolong rendah. Hal ini dapat dibuktikan dengan hasil TIMSS pada tahun 2015 rata-rata persentase jawaban benar siswa Indonesia untuk seluruh soal pecahan adalah sebesar 24,45\%. Persentase ini jauh di bawah rata-rata internasional, yaitu 46,98\%. Kemampuan siswa Indonesia pada soal pecahan juga lebih rendah dari kemampuan siswa dari negara dengan skor TIMSS 2015 di bawah Indonesia, yaitu Arab Saudi dengan rata-rata 29,42\%; Kuwait dengan rata-rata $25,18 \% .^{3}$ Selain itu rendahnya

\footnotetext{
2 Mohammad Faizal Amir, "Analisis Kesalahan Mahasiswa PGSD Universitas Muhammadiyah Sidoarjo Dalam Menyelesaikan Soal Pertidaksamaan Linier," JURNAL EDUKASI: KAJIAN ILMU PENDIDIKAN. 1, no. 2 (2017): 131-146.

3 "Mengapa Konsep Pecahan Sulit Bagi Siswa Indoesia?," n.d., https://puspendik. kemdikbud.go.id/seminar/upload/Seminar\%20
} 
kemampuan siswa Indonesia pada pecahan juga terlihat dari hasil TIMSS Numeracy yang sebenarnya memiliki tingkat kesulitan lebih rendah dari TIMSS 2015. Pada TIMSS Numeracy ini rata-rata persentase jawaban benar siswa Indonesia sebesar 42,67\% sedangkan rata-rata internasional sebesar 47,33\%. Hasil siswa Indonesia pada TIMSS Numeracy juga lebih rendah dari persentase jawaban benar siswa negara dengan skor TIMSS di bawah Indonesia, yaitu Yordania sebesar 46,7\% dan Afrika Selatan sebesar $48,72 \%$.

Hasil tersebut menunjukkan bahwa kemampuan siswa Indonesia dalam materi pecahan masih rendah karena empat dari lima negara dengan skor TIMSS di bawah Indonesia memiliki persentase jawaban benar yang lebih tinggi. ${ }^{4} \mathrm{Hal}$ itu disebabkan karena beberapa hal diantaranya kurikulum Indonesia mengenalkan pecahan lebih dini dibandingkan kurikulum negara lain yang lebih menekankan pada pemahaman konsep di awal siswa belajar pecahan. Adanya pembatasan terhadap pengertian pecahan hanya sebagai bagian dari keseluruhan. Padahal konteks pecahan mencakup (1) pecahan sebagai bagian dari keseluruhan, (2) pecahan sebagai bagian dari sekumpulan benda, dan (3) pecahan sebagai posisi pada garis bilangan. ${ }^{5}$ Selain itu juga dikarenakan siswa Indonesia hanya mampu menguasai soal-soal yang bersifat rutin, komputasi sederhana dan mengukur kemampuan akan fakta yang berkonteks keseharian. Akan tetapi belum mampu untuk menguatkan kemampuan mengintegrasikan informasi, menarik

Puspendik\%202017/Mengapa\%20konsep\%20 pecahan $\% 20$ sulit $\% 20$ bagi $\% 20$ s is wa $\% 20$ Indonesia\%20-\%20Rahmah.pdf.

4 "Mengapa Konsep Pecahan Sulit Bagi Siswa Indoesia?"

5 "Mengapa Konsep Pecahan Sulit Bagi Siswa Indoesia?" kesimpulan serta menggeneralisir pengetahuan yang dimiliki ke hal yang lain. ${ }^{6}$

Hal lain yang menunjukkan rendahnya pemahaman tentang pecahan juga ditunjukkan oleh mahasiswa PGMI IAIN Ponorogo sebagi calon guru SD/MI. Dari hasil tes soal tentang pemahaman terkait konsep pecahan dari seluruh mahasiswa PGMI yang menenempuh mata kuliah pembelajaran matematika di MI/SD hanya sekitar 21,69\% yang dapat memahami dengan benar sisanya menunjukkan bahwa terdapat kesulitan dan pemahaman tentang pecahan. Sehingga ketika mahasiswa diminta untuk menjelaskan tentang bagaimana cara mengajarkan pecahan kepada siswa SD/MI banyak mengalami kesalahan. Hal ini menarik perhatian saya sebagai pengampu mata kuliah tersebut untuk mengkaji permasalahan apa saja yang menyebabkan kesulitan yang dialami mahasiswa serta menganalisinya. Sehingga dengan dilakukannya diagnosis yang mendalam tentang jenis-jenis kesulitan yang dialami mahasiswa serta faktor-faktor penyebabnya akan sangat efektif untuk menanggulangi dan mengetahui kesulitankesulitan yang terjadi pada materi pecahan tersebut.

Menurut Thorndike dan Hagen diagnosis dapat diartikan sebagai (1) upaya atau proses menemukan kelemahan atau penyakit apa yang dialami seseorang dengan melalui pengujian dan studi yang sesama mengenai gejala-gejalanya (2) studi yang seksama terhadap fakta sesuatu hal untuk menemukan karakteristik atau kesalahankesalahan dan sebagainya yang esensial, (3) keputusan yang dicapai

\footnotetext{
6 Rahmawati, "Seminar Hasil TIMSS 2015," n.d., https://puspendik.kemdikbud.go.id/seminar/ upload/Hasil\%20Seminar $\% 20$ Puspendik $\% 20$ $2016 / \mathrm{Rah}$ mawati-Seminar \% $20 \mathrm{Hasil} \% 20$ TIMSS\%202015.pdf.
} 
setelah dilakukan studi yang seksama atas gejala-gejala atau fakta tentang suatu hal. ${ }^{7}$

Kesulitan belajar dalam mata pelajaran matematika memiliki corak dan karakteristik tersendiri apabila dibandingkan dengan kesulitan belajar dalam mata pelajaran yang lain. Menurut Wood $^{8}$ bahwa beberapa karakteristik kesulitan siswa dalam belajar matematika adalah : (1) kesulitan membedakan angka, simbol-simbol, serta bangun ruang, (2) tidak sanggup mengingat dalil-dalil matematika, (3) menulis angka tidak terbaca atau dalam ukuran kecil, (4) tidak memahami simbol-simbol matematika, (5) lemahnya kemampuan berpikir abstrak, (6) lemahnya kemampuan metakognisi (lemahnya kemampuan mengidentifikasi serta memanfaatkan algoritma dalam memecahkan soal-soal matematika). Sedangkan menurut Radatz kesalahan yang sering dilakukan siswa adalah kesalahan dalam penggunaan bahasa matematika dengan bahasa sehari-hari, kemampuan dalam keruangan, kemampuan dalam penguasaan prasyarat, kesalahan dalam penguasaan teori, dan kesalahan dalam penerapan aturan yang relevan. ${ }^{9}$

Berdasarkan pengertian diagnostik dan pengertian kesulitan belajar seperti terurai di depan maka pengertian diagnosis kesulitan belajar dapat dirangkum dari kedua pengertian tersebut. Jadi definisi dari diagnosis kesulitan belajar adalah suatu proses upaya untuk memahami jenis dan karakteristik serta latar belakang kesulitan-

\footnotetext{
7 Erny Untari, "Diagnosis Kesulitan Belajar Pokok Bahasan Pecahan Pada Siswa Kelas V Sekolah Dasar," Jurnal Ilmiah STKIP PGRI Ngawi 13, no. 01 (2013): 1-8.

8 Derek Wood, "Kiat Mengatasi Gangguan Belajar," Diterjemahkan Oleh Ivan Taniputera. Jogjakarta: Katahati, 2007, 68.

9 Hendrik Radatz, "Error Analysis in Mathematics Education," Journal for Research in Mathematics Education, 1979, 163-172.
}

kesulitan belajar dengan menghimpun dan mempergunakan berbagai data / informasi selengkap dan seobyektif mungkin sehingga untuk mengambil kesimpulan dan keputusan serta mencari alternatif kemungkinan pemecahannya.

Prosedur Diagnosis Kesulitan Belajar Ross dan Stanley ${ }^{10}$ menggariskan tahapantahapan diagnosis (the level of diagnosis) itu sebagai berikut : 5. How can errors be prevented? Bagaimana kelemahan itu dapat dicegah? 4. What remedies are suggested? Penyembuhan-pentembuhan apakah yang disarankan? 3. Why are the errors occur? Mengapa kelemahan-kelemahan itu terjadi? 2. Where are the errors located? Di manakah kelemahan-kelemahan itu dapat dialokasikan? 1.How are the pupils having trouble? Siapa-siapa siswa yang mengalami gangguan?

Menurut Tampomas ${ }^{11}$ bilangan Pecahan Pengertian Bilangan Pecahan Bilangan pecahan adalah bilangan rasional yang dinyatakan dalam bentuk $\mathrm{X}=$, dengan a bilangan bulat dan b bilangan asli, bilamana a tidak habis dibagi b. A dinamakan pembilang dan $b$ dinamakan penyebut. Suatu pecahan dapat dinyatakan dalam bentuk $\mathrm{X}=\frac{a}{b}$ dengan $\mathrm{b} \neq 0$, a disebut pembilang dan $b$ disebut penyebut. Operasi Hitung Utama Pada Himpunan Bilangan Operasi hitung pada himpunan bilangan disebut operasi hitung. 1) Penjumlahan 2) Pengurangan 3) Perkalian 4) Pembagian

Pada jenjang SD/MI penguasaan terhadap materi pecahan akan sangat dibutuhkan oleh guru. Karena pada jenjang tersebut materi pecahan sudah mulai diajarkan. Akan tetapi apabila seorang guru dalam mengajarkan banyak terjadi

${ }^{10}$ Untari, "Diagnosis Kesulitan Belajar Pokok Bahasan Pecahan Pada Siswa Kelas V Sekolah Dasar," 1-8.

11 Untari, 1-8. 
kesalahan sama seperti ketika masih menjadi mahasiswa maka dapat dipastikan bahwa siswa yang diajar juga akan mengalami hal yang sama bahkan mungkin bisa jauh lebih kompleks. Oleh karena itu sebagai mahasiswa calon guru SD/MI harus mempunyai bekal penguasaan materi SD yang cukup dan memadai.

Hal tersebut senada dengan yang disampaikan oleh Irhan dan Wijayani ${ }^{12}$ bahwa seorang guru harus memiliki ilmu pengetahuan tentang bidang studi yang menjadi keahlian yang yang diajarkan. Selain itu Hudojo ${ }^{13}$ juga menyatakan bahwa seorang guru matematika yang tidak menguasai materi matematika maka dipastikan guru tersebut tidak akan dapat mengajar matematika dengan baik.

Berdasarkan uraian tersebut maka penelitian ini bertujuan untuk mendiagnosis permasalahan yang terjadi pada mahasiswa PGMI IAIN Ponorogo yang sedang menempuh mata kuliah pembelajaran matematika di SD/MI dalam membelajarkan bilangan pecahan serta faktor penyebabnya.

\section{B. METODE PENELITIAN}

Penelitian ini adalah penelitian deskriptif kualitatif yang menghasilkan data mengenai permasalahan mahasiwa PGMI IAIN Ponorogo yang menempuh mata kuliah pembelajaran matematika di SD/MI dalam membelajarkan bilangan pecahan. Instrumen dalam penelitian ini yaitu peneliti itu sendiri sebagi instrument utama dan instrument pendukung berupa soal tes tentang bilangan pecahan yang hasilnya akan didiagnosis untuk mengetahui tentang permasalahan-permasalahan

\footnotetext{
12 Amir, "Analisis Kesalahan Mahasiswa PGSD Universitas Muhammadiyah Sidoarjo Dalam Menyelesaikan Soal Pertidaksamaan Linier."

13 Amir.
}

mahasiswa PGMI dalam membelajarkan bilangan pecahan.

\section{HASIL DAN PEMBAHASAN \\ Dugaan Penyebab Kesulitan}

Dari hasil tes yang diberikan kepada mahasiswa PGMI yang menempuh matakuliah pembelajaran matematika di SD/MI ternyata sebagian besar mahasiswa kurang memahami tentang konsep dalam pecahan. Adapun hasil dugaan penyebab kesulitan mahasiswa dalm membelajarkan pecahan pada siswa MI/SD sebagai berikut:

\section{Mahasiswa kesulitan dalam} membelajarkan makna dari pecahan misalnya $\frac{1}{2}, \frac{1}{4}, \frac{3}{4}$

Sebagian besar mahasiswa hanya memahami bahwa makna pecahan adalah bagian dari keseluruhan.yang digambarkan mahasiswa dalam bentuk seperti gambar berikut:
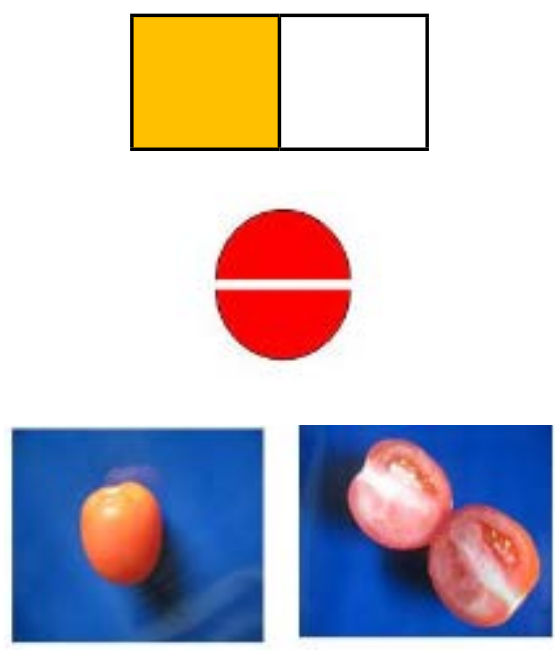

Gambar 1. Makna Pecahan bagian dari keseluruhan

Padahal makna pecahan tidak hanya sebagai bagian dari keseluruhan saja akan tetapi juga bermakna sebagai bagian dari sekumpulan benda atau juga menyatakan pembagian. Sehingga pecahan setengah juga dapat dinyatakan dalam bentuk berikut: 


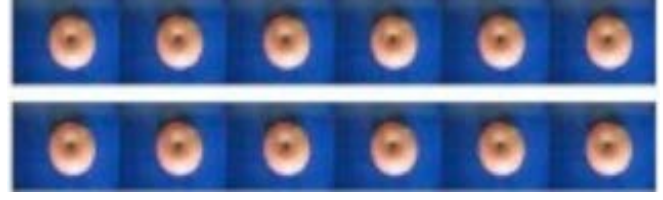

Gambar 2. Makna pecahan bagian dari sekumpulan benda

Gambar 2. Di atas menunjukkan bahwa terdapat 12 kue donat yang dikelompokkan menjadi 2 sehingga ketika diubah kedalam kalimat matematika menjadi:

$$
12: 2=6 \text { atau } \frac{1}{2} \times 12=6
$$

Selain itu pecahan juga bermakna sebagai perbandingan rasio

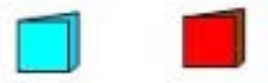

\section{Buku Biru Buku Merah}

\section{Gambar 3. Makna Pecahan sebagai} perbandingan rasio

Perbandingan buku biru terhadap keseluruhan buku dapat dituliskan $1: 2$

Dari hasil jawaban mahsiswa menunjukkan bahwa hamper sebagian besar mahasiswa memahami makna pecahan hanya sebagai bagian dari keseluruhan saja. Hali ini menjadi salah satu penyebab kesulitan scalon guru SD/ MI dalam membelajarkan makna pecahan.

\section{Kesulitan dalam membelajarkan}

pecahan yang senilai, misal $\frac{1}{2}=\frac{2}{4}=\frac{3}{6}=\frac{4}{8}$

Ketika mahasiswa diminta untuk menjelaskan tentang pecahan senilai dari $\frac{1}{2}$ hampir keseluruhan dari hasil tes mahasiswa menunjukkan cara menjelaskan yang sama sebagai berikut:

$$
\frac{\not 2}{4}=\frac{1}{2} \quad \frac{3}{6}=\frac{1}{2} \quad \frac{4}{b}=\frac{1}{2}
$$

Dari jawaban mahasiswa menunjukkan bahwa dalam membelajarkan pecahan sebanding atau senilai langsung dengan membagi pembilang dan penyebut dengan bilangan yang paling sederhana. Cara ini tidak salah hanya saja ketika diajarkan kepada siswa SD/MI yang baru mengenal bilangan pecahan akan menjadi sangat sulit karena makna dari pecahan senilai tidak danpat dipahami oleh siswa.

Untuk membantu siswa dalam memahamkan makna dari pecahan senilai dapat digunakan potongan potongan

\begin{tabular}{|c|c|c|c|c|c|}
\hline & & 1 & & & \\
\hline & $\frac{1}{2}$ & & & & \\
\hline & $\frac{1}{3}$ & & $\frac{1}{3}$ & & \\
\hline$\frac{1}{4}$ & & $\frac{1}{4}$ & $\frac{1}{4}$ & & \\
\hline & & & \begin{tabular}{l|l}
1 & 1 \\
5 & $\frac{1}{5}$
\end{tabular} & & $\frac{1}{5}$ \\
\hline$\frac{1}{6}$ & $\frac{1}{6}$ & $\frac{1}{6}$ & $\frac{1}{6}$ & $\frac{1}{6}$ & $\frac{1}{6}$ \\
\hline$\frac{1}{7}$ & $\frac{1}{7}$ & $\frac{1}{7}$ & \begin{tabular}{|l|l|}
1 & 1 \\
7 & $\frac{1}{7}$ \\
\end{tabular} & $\frac{1}{7}$ & $\frac{1}{7}$ \\
\hline \begin{tabular}{l|l}
$\frac{1}{8}$ \\
\end{tabular} & & $\frac{1}{8}$ & \begin{tabular}{|l|l|}
$\frac{1}{8}$ & $\frac{1}{8}$ \\
\end{tabular} & & \begin{tabular}{|l|}
$\frac{1}{8}$ \\
\end{tabular} \\
\hline
\end{tabular}
karton pada gambar berikut:

Gambar 4. Ilustrasi makna dari pecahan senilai

Dari potongan karton dapat dikembangkan fakta bahwa karton dengan nilai dua perempat dapat menutup karton setengahan, karton dengan nilai tiga perenam dapat meutup karton dua perempatan, karton dengan nilai empat perdelapanan dapat menutup karton tiga perenaman, karton dengan nilai lima persepuluhan dapat menutup karton dengan nilai empat perdelapanan. Dengan melihat-fakta-fakta yang ditunjukkan maka dalam memeblajarkan pecahan senilai atau sebanding siswa dapat diajak dengan melihat pola sehingga mereka akan sampai pada kesimpulan bahwa pecahan yang sebanding adalah perkalian oleh bilangan yang sama terhadap pembilang 
dan penyebut suatu pecahan menghasilkan pecahan-pecahan yang senilai.

Contoh lain yang bisa kita tunjukkan adalah dengan melipat strip kertas. Di mana setiap melipat melipat 2 bagian yang sama akan memunculkan nama-nama yang berbeda dari pecahan, tetapi pecahan tersebut memiliki nilai yang sama. Lipatan pertama adalah $\frac{1}{2}$, lipatan kedua $\frac{2}{4}$, lipata $\frac{4}{8}$ ketiga $\frac{3}{6}$ adalah dan lipatan keempat dengan hasil lipatan yang menunjukkan bahwa $\frac{1}{2}=\frac{2}{4}=\frac{3}{6}=\frac{4}{8}$

Selain melipat secara genap, kita juga dapat melipat menjadi bagian ganjil yang sama. Sebagai contoh lipatan pertama $\frac{1}{3}$, lipatan kedua $\frac{1}{6}$ dan seterusnya.

\section{Kesulitan dalam membelajarkan penjumlahan bilangan bilangan pecahan jika mempunyai penyebut yang tidak sama, misal $\frac{1}{2}+\frac{2}{3}$}

Salah satu kesulitan mahasiswa dalam membelajarkan pecahan adalah ketika mereka bertemu dengan penjumlahan yang mempunyai penyebut yang tidak sama. Bahkan mahasiswa kesulitan dalam mengilustrasikan bagaimana membelajarkan penjumlahan pecahan yang mempunyai penyebut tidak sama. Hampir keseluruhan mahasiswa menjawab hasil tes dengan megilustrasikan jawabannya sebagi berikut:

$$
\frac{1}{2}+\frac{1}{3}=\frac{(3 \times 1)+(2 \times 1)}{6}=\frac{3+2}{6}=\frac{5}{6}
$$

Mahasiswa menjawab dengan prosedur yang benar. hanya saja mahasiswa tidak memahami kenapa dalam penjumlahan pecahan apabila penyebutnya tidak sama harus disamakan terlebih dahulu. Sehingga mahasiswa tidak dapat mengeksplorasikan hasil jawabannya kedalam bentuk yang lebih kongrit dalam membelajarkan pecahan kepada siswa. Adapun proses penjumlahan pecahan yang penyebutnya tidak sama dapat diilustrasikan sebagai berikut:

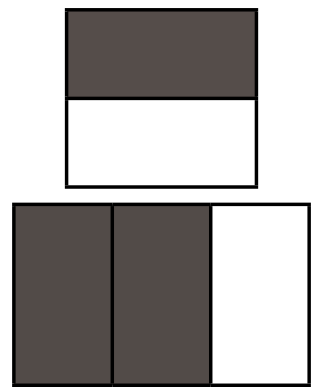

Gambar 5. Ilustrasi Penjumlahan pecahan dengan penyebut tidak sama

Penjumlahan dua pecahan yang dengan penyebut berbeda dapat diilustrasikan salah atunya dengan model daerah yang dibedakan menjadi daerah vertikal dan horizontal. Perhatkan:agar masing-masing bagian mempunyai bagian yang sama maka bagian dipotong vertikal menjadi tiga bagian yang sama. Sedangkan bagian dibagi dipotong secara horizontal menjadi 2 bagian yang sama. Sehingga tiap bagian akan menghasilkan 6 bagian yang sama.

Atau dengan menggunakan kembali potongan karton dengan menyambungkan bagian potongan masing-masing memnjang keluar sebagai pernyataan penambahan. Adapun ilustrasinya sebagai berikut:

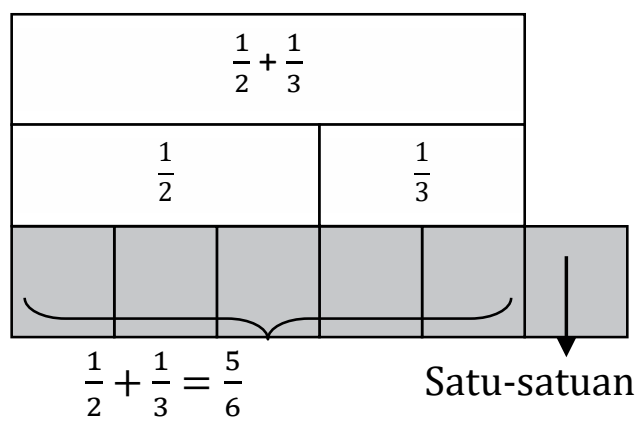

Gambar 6. Hasil Ilustrasi Penjumlahan dan Pengurangan dengan penyebut tidak sama 


\section{Kesulitan dalam membelajarkan} pengurangan bilangan pecahan dengan penyebut tidak sama, misal $\frac{2}{3}-\frac{1}{2}$

Selain mengalami kesulitan dalam hal membelajarkan operasi penjumlahan dua pecahan dengan penyebut yang tidak sama mahasiswa juga mengalami kesulitan dalam hal membelajarkan pengurangan dua pecahan dengan penyebut berbeda. Hal ini terlihat dari hasil jawaban mahasiswa yaitu mayoritas mahasiswa menyelesaikan dengan cara menyamakan penyebutnya terlebuh dahulu kmudian mengurangkan pembilangnya.

$$
\frac{2}{3}-\frac{1}{2}=\frac{(2 \times 2)-(3 \times 1)}{6}=\frac{4-3}{6}=\frac{1}{6}
$$

Keseluruhan mahasiswa menjawab dengan cara seperti di atas. Secara konsep hal tersebut benar akan tetapi dalam memahamkan konsep pengurangan dua pecahan dengan penyebut yang berbeda siswa perlu dipahamkan kenapa dalam pengurangan dua pecahan dengan penyebut tidak sama penyebutnya harus disamakan. Dalam membelajarkan kepada siswa hal terssebut dapat diilustrasikan dengan menggunakan model daerah yang dibedakan menjadi daerah horizontal dan daerah vertikal dengan langkah sebagai berikut:

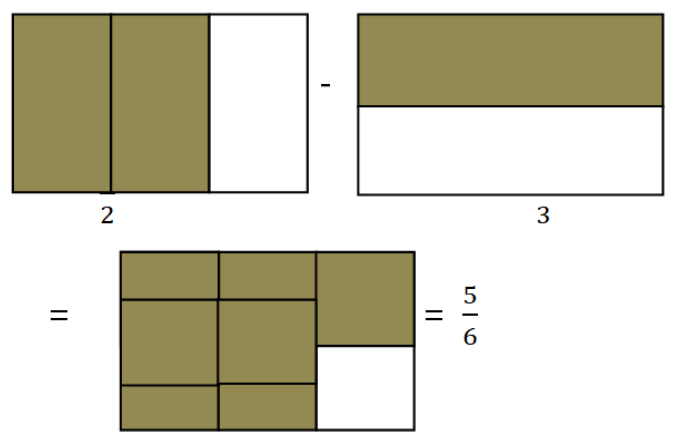

Gambar 7. Ilustrasi hasil pengurangan pecahan dengan penyebut berbeda
Pertama ambillah $\frac{1}{2}$ dari $\frac{2}{3}$ dengan berfikir bahwa daerah $\frac{2}{3}$ yang tertutupi (vertical) oleh daerah $\frac{1}{2}$ (horizontal) adalah daerah yang terambil. Perlu diperhatikan bahwa tidak semua daerah $\frac{2}{3}$ tertutupi oleh daerah $\frac{1}{2}$ sehingga daerah yang tidak tertutupi yang merupakan kombinasi dari daerah vertial dan horizontal itulah yang merupakan hasil dari sisa pengambilan $\frac{1}{2}$ dari $\frac{2}{3}$. Sehingga sisanya yaitu $\frac{1}{6}$. Hal yang perlu dipahami disini adalah bahwa penyebut disamakan karena untuk untuk membagi bagian itu menjadi bagian yang sama agara dapat dikurangkan.

\section{Kesulitan dalam membelajarkan perkalian pecahan, misal $\frac{1}{2} x \frac{1}{4}$}

Dalam membelajarkan bentuk perkalian pecahan mahasiswa calon guru SD/MI juga mengalami kesulitan dalam hal perkalian pecahan. Mahasiswa secara konsep menjawab sudah benar yaitu dengan cara mengalikan pembilangn dengan pembilang dan penyebut dengan penyebut. Akan tetapi tidak memahami makna apa makna dari $\frac{1}{2} x \frac{1}{4}=\frac{1}{8}$

Makna dari dapat diilustrasikan sebagai berikut. Sebagai contoh: Ratna hari ini berulang tahun dan mendapatkan hadiah dari ayahnya berupa kue ulang tahun. Setelah dibagi kepada temantemannya kue ulang tahunnya tersisa . Ratna kemudian memakan dari kue yang tersisa. Berapa bagian kue yang yang dimakan Ratna? Permasalahan ini dapat ditulisakan dengan atau dari . Jika diilustrasikan dalam bentuk daerah dapat digambarkan sebagai berikut: 


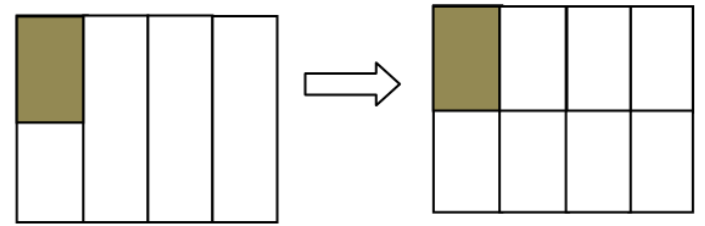

$$
\begin{array}{r}
\frac{1}{2} \operatorname{dari} \frac{1}{4}=\frac{1}{8} \\
\operatorname{atau} \frac{1}{2} \times \frac{1}{4}=\frac{1}{8}
\end{array}
$$

Gambar 8. Ilustrasi Membelajarkan Perkalian Pecahan

\section{Mahasiswa mengalami kesulitan} dalam membelajarkan makna dan hasil pembagian, misal $1: \frac{2}{3}, 3: \frac{3}{4}$

Dalam membelajarkan pembagian bilangan bulat dengan bilangan pecahan mahasiswa calon guru SD/MI cenderung langsung menggunakan cara dengan mengalikan kebalikan dari bilangan pembaginya yaitu sebagai berikut:

$$
\begin{aligned}
& 1: \frac{2}{3}=1 \times \frac{3}{2}=\frac{3}{2} \\
& 3: \frac{3}{4}=3 \times \frac{4}{3}=\frac{12}{3}=4
\end{aligned}
$$

Dari jawaban diatas menunjukkan bahwa kecenderungan mahasiswa hanya memahami secara komputasi sederhana sasja tanpa mengetahui apa makna dari pembagian $1: \frac{2}{3}, 3: \frac{3}{4}$. Untuk membantu mahasiswa yang mengalami kesulitan dalam membelajarkan 1: $\frac{2}{3}, 3: \frac{3}{4}$ tentang hal ini, maka diilustrasikan dengan potongan kue.

Misalkan untuk menjelaskan tentang hal tersebut maka perlu dipahami dulu makna dari . dari 1: $\frac{2}{3}$. Makna dari $1: \frac{2}{3}$ sama dengan mencari banyaknya nilai dua pertigaan dalam satu satuan. Perhatikan gambar berikut

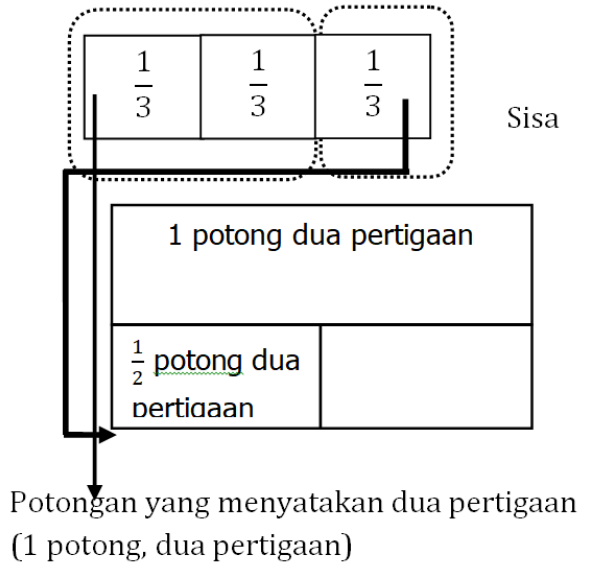

Gambar 9. Ilustrasi membelajarkan Hasil Pembagian Pecahan 1: $\frac{2}{3}$

Dari gambar ilustrasi di atas menunjukkan bahwa adanya sebuah potongan kertas atau kue dengan nilai dua pertigaan dan sisanya satu buah potongan kue dengan nilai setengah dari dua pertigaan berupa satu pertigaan. Selanjutnya kita akan gunakan potongan kue pertigaan sebagai satuan baru, sehingga potongan kue satu pertigaan (sisa) menjadi bernilai $\frac{1}{2}$

$$
\text { Jadi, } 1: \frac{2}{3}=1+\frac{1}{1}=1 \frac{1}{2}
$$

Selanjutnya untuk pembagian $1: \frac{3}{4}$ dapat juga dijelaskan seperti susunan di atas. Perhatikan ilustrasi berikut:

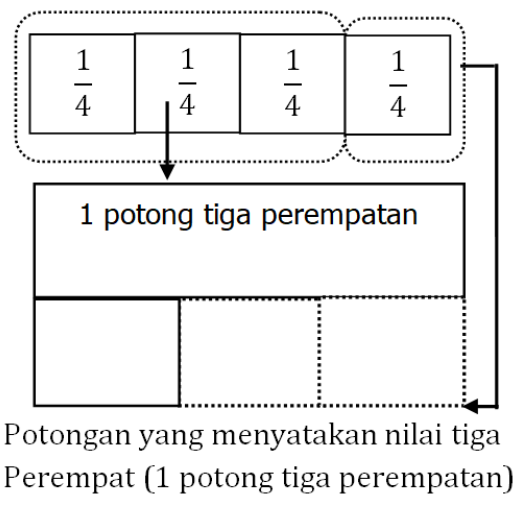

Gambar 10. Ilustrasi membelajarkan Hasil Pembagian Pecahan 1: $\frac{3}{4}$

Dari ilustrasi di atas digambarkan tiga perempatan dan sisanya satu buah potongan kue dengan nilai sepertiga dari tiga perempatan berupa satu pertigaan. Selanjutnyakitaakangunakan potongan kue 
perempatan sebagai satuan baru, sehingga potongan kue satu pertigaan (sisa) menjadi bernilai $\frac{1}{3}$, sehingga $1: \frac{3}{4}=1+\frac{1}{3}=1 \frac{1}{3}$ hal ini menunjukkan fakta bahwa $\frac{a}{b}: \frac{c}{d}=\frac{a}{b}: \frac{d}{c}$

\section{PENUTUP}

Berdasarkan deskripsi di atas beberapa kesulitan atau permasalahan yang dialamai mahasiswa calon guru SD/MI dalam membelajarkan bilangn pecahan diantaranya yaitu: 1) kesulitan dalam membelajarkan makna pecahan, 2) kesulitan dalam membelajarkan pecahan senilai, 3) Kesulitan dalam membelajarkan penjumlahan bilangan bilangan pecahan jika mempunyai penyebut yang tidak sama, 4) Kesulitan dalam membelajarkan pengurangan bilangan pecahan dengan penyebut tidak sama, 5) Kesulitan dalam membelajarkan perkalian pecahan, 6) Mahasiswa mengalami kesulitan dalam membelajarkan makna dan hasil pembagian pecahan.

\section{DAFTAR PUSTAKA}

Amir, Mohammad Faizal. "Analisis Kesalahan Mahasiswa PGSD Universitas Muhammadiyah Sidoarjo Dalam Menyelesaikan Soal Pertidaksamaan Linier." JURNAL EDUKASI: KAJIAN ILMU PENDIDIKAN. 1, no. 2 (2017): 131-146.

Fatmahanik, Ulum. "Realistic Mathematic Education (RME) Dalam Meningkatkan Hasil Belajar Matematika." Ibriez: Jurnal Kependidikan Dasar Islam Berbasis Sains 1, no. 1 (2016): 19-34.

"Mengapa Konsep Pecahan Sulit Bagi Siswa Indoesia?," n.d. https://puspendik. kemdikbud.go.id/seminar/upload/ Seminar\%20Puspendik\%202017/ Mengapa\%20konsep\%20pecahan\%20 s u lit $\% 20$ b a g i \% 20 s is wa \% 20 Indonesia\%20-\%20Rahmah.pdf.

Radatz, Hendrik. "Error Analysis in Mathematics Education." Journal for Research in Mathematics Education, 1979, 163-172.

Rahmawati. "Seminar Hasil TIMSS 2015," n.d. https://puspendik.kemdikbud. go.id/seminar/upload/Hasil\%20 Seminar\%20Puspendik\%202016/ Rahmawati-Seminar\%20Hasil\%20 TIMSS\%202015.pdf.

Untari, Erny. "Diagnosis Kesulitan Belajar Pokok Bahasan Pecahan Pada Siswa Kelas V Sekolah Dasar." Jurnal Ilmiah STKIP PGRI Ngawi 13, no. 01 (2013): 1-8.

Wood, Derek. "Kiat Mengatasi Gangguan Belajar." Diterjemahkan Oleh Ivan Taniputera. Jogjakarta: Katahati, 2007. 